\title{
Ethnoarchéologie et ethnologie des techniques
}

\section{Anick Coudart et Pierre Lemonnier}

\section{OpenEdition}

Journals

Édition électronique

URL : https://journals.openedition.org/tc/1017

DOI : $10.4000 /$ tc. 1017

ISSN : 1952-420X

Éditeur

Éditions de l'EHESS

Édition imprimée

Date de publication : 1 juin 1984

ISSN : 0248-6016

\section{Référence électronique}

Anick Coudart et Pierre Lemonnier, «Ethnoarchéologie et ethnologie des techniques », Techniques \& Culture [En ligne], 3 | 1984, mis en ligne le 26 janvier 2006, consulté le 29 septembre 2022. URL : http:// journals.openedition.org/tc/1017; DOI : https://doi.org/10.4000/tc.1017

Ce document a été généré automatiquement le 29 septembre 2022

Tous droits réservés 


\section{Ethnoarchéologie et ethnologie des techniques}

Anick Coudart et Pierre Lemonnier 